\title{
Epidemiological Analysis of Risk Factors for Breast Cancer in Indonesian Females
}

\author{
Setyawati Budiningsih", Yoshiyuki Ohno ${ }^{\dagger}$, Joedo Prihartono", Muchlis Ramli ${ }^{\ddagger}$, Kenji Wakai $^{\dagger}$, \\ Santoso Cornain ${ }^{p * *}$, Idral Darwis $^{\ddagger}$, Sadao Suzuki ${ }^{\dagger}$, Didid Tjindarbumi ${ }^{\ddagger}$, Susumu Watanabe ${ }^{\S}$, \\ Gunawan Tjahjadi I", Goi Sakamoto", Esti Soetrisno $\mid$, Endang Sri Roostini $\mid l$
}

\begin{abstract}
Abstrak
Untuk menetapkan faktor-faktor risiko pada perkembangan kanker payudara dilakukan penelitian epidemiologik selama 3-tahun yang termasuk pada penelitian kerjasama antara Indonesia dan Jepang. Metoda kasus-kontrol dipilih dan digunakan penderita yang mengunjungi Rumah Sakit Pusat Nasional Dr. Cipto Mangunkusumo, Jakarta. Tiga ratus kasus kanker payudara yang baru dan diperkuat dengan pemeriksaan histopatologik diadu berpasangan, menurut umur (+/-3 tahun) dan status sosioekonomik, dengan 600 kontrol. Data yang dikumpulkan adalah data demografik, pajanan terhadap radiasi, hubungan genetik, pola makanan dan kebiasaan hidup lainnya. Analisa data dilakukan dengan cara univariat. Hasilnya menunjukkan bahwa beberapa faktor meningkatkan risiko kanker payudara, yaitu trauma pada payudara, berat badan rendah, menopause yang alamiah, menopause yang diinduksi, jumlah kehamilan rendah (1-2 kali), masa menyusukan bayi yang singkat (kurang dari 4 bulan), hubungan keluarga dekat dengan penderita kanker payudara dan konsumsi makanan berlemak. Faktor-faktor yang menurunkan risiko kanker payudara adalah status perkawinan yang berpisah, keadaan menduda, berat badan berlebihan, siklus haid tidak teratur. Disimpulkan bahwa faktor risiko yang paling mencolok adalah 1). menopause yang diinduksi dan 2). masa menyusui bayi singkat (kurang dari 4 bulan) (Risiko Relatif masing-masing 5.96 dan 5,44). Peningkatan risiko kanker payudara dua sampai tiga kali pada keadaan berat badan rendah dan konsumsi makanan berlemak (Risiko Relatif masing-masing 2.85 dan 2.63). Oleh karena konsumsi makanan berlemak merupakan salah satu faktor risiko yang bermakna, penelitian diperpanjang dengan analisa gizi yang lebih lanjut.
\end{abstract}

\begin{abstract}
To identify risk factors in breast cancer development a 3-year epidemiological study was carried out in the joint research project between Indonesia and Japan. Case-control method has been chosen and patients visiting Dr. Cipto Mangunnkusumo National General Hospital, Jakarta were used. Three hundred cases, newly diagnosed primary breast cancer patients, confirmed with histopathological examination were matched by age $(+/-3$ years $)$ and socio-economic status with 600 controls. Data collected were demographics, reproductives, breast trauma, radiation exposure, genetical traits, dietary pattern and other lifestyles. The epidemiological data were analyzed by univariate method. The results showed that several factors increased breast cancer risk, namely breast trauma, undenveight, naturally occuring menopause, induced menopause, infrequent (1-2 times) pregnancy, short period (less than 4 months) breast feeding, close genetic trait with breast cancer patient and fatty food consumption. Factors reducing the risk of breast cancer were separated marital status, widowed, overweight and irregular menstrual cycle It was concluded that the most prominent risk factors were 1) induced menopause and 2) short period (less than 4 months) breast feeding (Relative Risk of 5.96 and 5.44 respectively). The risk of breast cancer was twice to thrice in patients with underweight, among close genetic traits and those consuming fatty food (Relative Risk of 2.2, 2.85 and 2.63 respectively). Since fatty food consumption was found as one of the significant risk factors, the study has been extended with further nutritional analysis.
\end{abstract}

Keywords: case-control study, risk factors, breast cancer

\footnotetext{
Department of Community Medicine, Faculty of Medicine, University of Indonesia, Jakarta 10320, Indonesia;

† Department of Preventive Medicine, School of Medicine, Nagoya University, Nagoya 466, Japan;

¥ Department of Surgery, Faculty of Medicine, University of Indonesia and Dr. Cipto Mangunkusumo National Central General Hospital Jakarta 10430, Indonesia;

\$ Department of Surgery, Cancer Institute, Tokyo 170, Japan;

II Department of Anatomic-Pathology, Faculty of Medicine, University of Indonesia, Jakarta 10430, Indonesia;

"Department of Pathology, Cancer Institute, Tokyo 170, Japan;

** Research Center for Medical Science and Technology, Faculty of Medicine, University of Indonesia, Jakarta 10430, Indonesia.
}

According to the last demographic census, Indonesian women experience longer life expectancy than ten years ago. Live longer means a higher possibility of manifesting chronic diseases. The last health statistics from Ministry of Health ${ }^{1}$ showed an increasing rank of chronic diseases morbidity and mortality. Cancer ranked the fifth in morbidity and the third in mortality. In women, breast cancer ranked the second after cervical cancer, 2,3 with relative frequency around $18 \%$ in pathology based and limited population based cancer registry. 
Many factors incriminated as having influences on the development of breast cancer. ${ }^{4,5}$ Changing life styles, long- term use of hormonal contraceptives and certain type of diet are known as potential risk factors. These behavioral changes are believed to have significant impact on the probability of contracting breast cancer in Indonesia as well. Some potential risk factors have been looked upon in descriptive study incorporated in clinical investigation. ${ }^{6}$

Most of the patients diagnosed as having breast cancer, were already in the late stages, and thus markedly reduced the efficiency of surgery, chemo- and radiotherapy. In order to improve the quality of health services including preventive measures for breast cancer, health managers need to have a clear and accurate information on which factors affect the development of this malignancy. Since various epidemiologic studies ${ }^{4,5}$ have been conducted in other populations, it is of importance to study risk factors in breast cancer development among Indonesian women. It is expected to look upon both the similarity and the dissimilarity with the accompanying study in Japanese women and other data.

The general hypothesis for this study was that Indonesian women with more modern life style will show a higher probability of getting breast cancer. Specific objectives of our study include a possible association of breast cancer with reproductive history, breast traumas, exposure to hormonal contraceptive, frequent exposure to radiation, close genetic traits and imbalanced dietary pattern.

\section{METHOD}

The study design adopted in this study was a CASECONTROL study design ${ }^{5,7}$ with a double matched control groups. The Dr. Cipto Mangunkusumo National Central General Hospital served as a source of cases and controls. Data collection from cases and controls had been carried out for 3 years, from November 1988 to December 1991.

Eligible cases in this study were women who had been newly diagnosed as having primary breast cancer, irrespective of its clinical stage. The diagnosis was made by histopathological examination of biopsied tissue. Matched controls were recruited from surgery department or other department of the same hospital.

Population for controls were women who were confirmed as having neither breast cancer nor lumps, and matched to the cases by age ( $+/-3$ years), and socioeconomic status, by the room category of hospitaliza- tion. Controls were collected twice as many as cases with 3 months recruitment phase for each triplet.

Based on statistical consideration ( $\alpha=0.05$ and $\beta=0.2)$ 300 triplets were colected.

Cases and controls were interviewed by two well trained nurses, using standardized questionaires. The questionaire were edited in advance by a supervisor before tabulation.

The case and control groups were tested for comparability on age and some socio-economic variables. Relative risk (RR) was estimated by computing the Odds ratio (age adjusted or adjusted for confounders by regression analysis). The significance of the RR was determined based on $95 \%$ confidence interval (CI).

\section{RESULTS}

The age distribution of the study subjects are given in Table 1. Mean ages were 46.9 for both cases and controls indicating no statistical difference and were well matched for age.

Table 1. Distribution of age among cases \& controls

\begin{tabular}{lccrl}
\hline \multirow{2}{*}{$\begin{array}{l}\text { Age } \\
\text { (yrs })\end{array}$} & \multicolumn{2}{c}{ Cases } & \multicolumn{2}{c}{ Control } \\
& $\mathrm{n}$ & $\%$ & $\mathrm{n}$ & $\%$ \\
\hline$<35$ & 51 & 17 & 104 & 17.3 \\
$35-39$ & 34 & 11.3 & 93 & 15.5 \\
$40-44$ & 51 & 17 & 71 & 11.8 \\
$45-49$ & 42 & 14 & 84 & 14 \\
$50-54$ & 29 & 9.7 & 64 & 10.7 \\
$55-59$ & 26 & 8.7 & 61 & 10.2 \\
$60-64$ & 46 & 15.3 & 73 & 12.2 \\
$65-69$ & 12 & 4 & 35 & 5.8 \\
$>70$ & 9 & 3 & 15 & 2.5 \\
\hline Total & 300 & \multicolumn{3}{|c}{600} \\
Mean & 46.9 & & 46.9 & \\
S.D & 12.1 & \multicolumn{3}{|c}{12.0}
\end{tabular}

The distribution of breast cancer cases according to clinical stage is given in Figure 1.

Figure 1. Percentage of Cases According to the Stage of Cancer

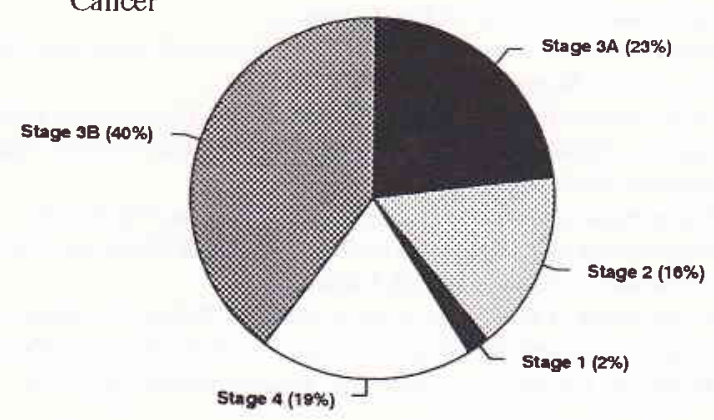


Educational attainment shows that all women were graduated from schools under university levels (see Table 2). Women graduated from senior high school were at smaller risk for breast cancer $(R R=0.41 ; 95 \%$ $\mathrm{CI}=0.2-0.87$ ).

Table 2. Relative risk of education among groups

\begin{tabular}{|c|c|c|c|c|c|c|}
\hline \multirow[t]{2}{*}{ Education } & \multirow{2}{*}{$\begin{array}{c}\text { Case } \\
\mathbf{n}\end{array}$} & \multicolumn{2}{|c|}{ Control } & \multirow{2}{*}{$\begin{array}{l}\mathrm{Rr} \\
\%\end{array}$} & \multicolumn{2}{|c|}{$95 \% \mathrm{Ci}$} \\
\hline & & $\%$ & n & & & \\
\hline Illiterate & 78 & 26.0 & 149 & 24.8 & 0.59 & $0.28-1.24$ \\
\hline Elementary & 108 & 36.0 & 195 & 32.5 & 0.63 & $0.30-1.30$ \\
\hline Junior.H.S & 46 & 15.3 & 93 & 15.5 & 0.56 & $0.26-1.21$ \\
\hline Senior.H.S & 53 & 17.7 & 146 & 24.4 & 0.41 & $0.20-0.87$ \\
\hline University & 15 & 5.0 & 17 & 2.8 & 1.00 & \\
\hline
\end{tabular}

Concerning the demographic origin, urban dwellers were at increased risk $(\mathrm{RR}=2.22 ; 95 \% \mathrm{CI}=1.63$ 3.02), as can be seen in Table 3 .

Table 3. Relative risk of geographical origin among groups

\begin{tabular}{|c|c|c|c|c|c|}
\hline \multirow[t]{2}{*}{ Geographic } & \multirow{2}{*}{$\begin{array}{c}\text { Cases } \\
n\end{array}$} & \multicolumn{2}{|c|}{ Controls } & \multirow{2}{*}{$\begin{array}{l}\mathrm{Rr} \\
\%\end{array}$} & \multirow{2}{*}{$95 \% \mathrm{Ci}$} \\
\hline & & $\%$ & $\mathbf{n}$ & & \\
\hline Rural & 105 & 35.0 & 117 & 29.5 & 1.0 \\
\hline Urban & 195 & 65.0 & 482 & 70.5 & $2.221 .63-3.02$ \\
\hline Total & 300 & & 599 & & 899 \\
\hline
\end{tabular}

Table 4 shows relative risk by marital status. Breast cancer risk was significantly smaller among separated or widowed as compared to married women .

Table 4. Relative risk of marital status among groups

\begin{tabular}{|c|c|c|c|c|c|c|}
\hline \multirow{2}{*}{$\begin{array}{l}\text { Marital } \\
\text { Status }\end{array}$} & \multicolumn{2}{|c|}{ Case } & \multicolumn{2}{|c|}{ Control } & \multirow[t]{2}{*}{$\mathrm{Rr}$} & \multirow[t]{2}{*}{$95 \% \mathrm{Ci}$} \\
\hline & n & $\%$ & $\mathrm{n}$ & $\%$ & & \\
\hline Married & 197 & 65.7 & 331 & 55.2 & 1.0 & \\
\hline Seperated & 16 & 5.3 & 72 & 12.0 & 0.37 & $0.21-0.65$ \\
\hline Widowed & 64 & 21.3 & 157 & 26.2 & 0.68 & $0.49-0.96$ \\
\hline Unmarried & 23 & 7.7 & 39 & 6.5 & 0.99 & $0.57-1.75$ \\
\hline Total & 300 & & 599 & & & \\
\hline
\end{tabular}

Breast trauma was proved to be a sigilificant breast cancer risk factor $(\mathrm{RR}=1.88 ; 95 \% \mathrm{CI}=1.09-3.25)$, as shown in table 5 .
Table 5. Relative risk of breast trauma among groups

\begin{tabular}{lrrrrrr}
\hline Trauma & \multicolumn{2}{c}{ Case } & \multicolumn{2}{c}{ Control } & Rr & $95 \% \mathrm{Ci}$ \\
& $\mathrm{n}$ & $\%$ & $\mathrm{n}$ & $\%$ & & \\
\hline Yes & $\mathbf{2 6}$ & $\mathbf{8 . 7}$ & $\mathbf{2 8}$ & $\mathbf{4 . 7}$ & $\mathbf{1 . 8 8}$ & $\mathbf{1 . 0 9 - 3 . 2 5}$ \\
No & 271 & 90.3 & 549 & 91.5 & 1.0 & \\
\hline Total & 297 & \multicolumn{7}{c}{577} & & & \\
\hline
\end{tabular}

It was found that under-weight (Body mass index/BMI less than 17) was a significant risk factor $(R R=2.22$; 95\% CI= 1.22 - 3.96), but over-weight (BMI: $22-25$ ) seemed to show protective effect $(\mathrm{RR}=0.32 ; 95 \% \mathrm{CI}$ $=0.22-0.45)$ as compared to normoweight (BMI : 17 - 21). See Table 6.

Table 6. Relative risk of body weight among groups

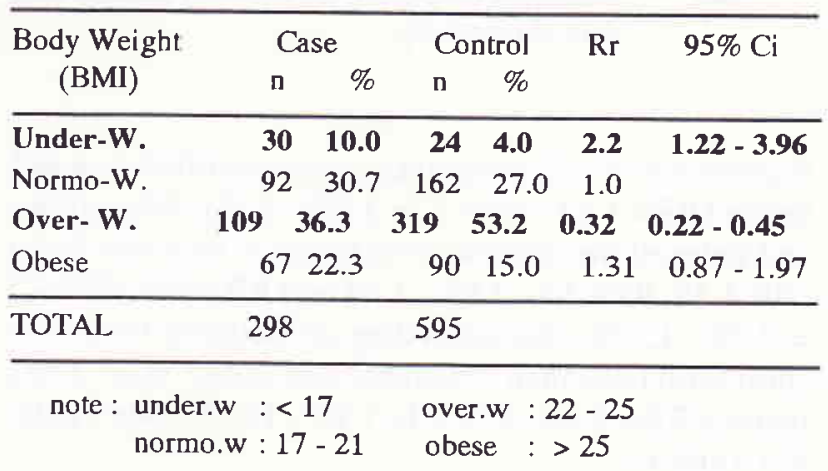

Tabel 7 shows that some irregular menstrual cycle might show protective effect $(\mathrm{RR}=0.08 ; 95 \% \mathrm{CI}=0.02$ $-0.4)$.

Table 7. Relative risk of menstrual type among groups

\begin{tabular}{|c|c|c|c|c|c|c|}
\hline \multirow{2}{*}{$\begin{array}{l}\text { Menstrual } \\
\text { Regularity }\end{array}$} & \multicolumn{2}{|c|}{ Case } & \multicolumn{2}{|c|}{ Control } & \multirow[t]{2}{*}{$\mathrm{Rr}$} & \multirow[t]{2}{*}{$95 \% \mathrm{Ci}$} \\
\hline & n & $\%$ & n & $\%$ & & \\
\hline Always reg & 216 & 72.0 & 391 & 65.2 & 1.0 & \\
\hline Some irr & 84 & 28.0 & 209 & 34.8 & 0.73 & $0.54-0.98$ \\
\hline Total & \multicolumn{2}{|l|}{300} & \multicolumn{2}{|l|}{600} & & \\
\hline note: alway & & \multicolumn{5}{|c|}{$\begin{array}{l}\text { : regularity for } 3 \text { period }(<20 \text {, } \\
\text { between } 20-30 \text { and over } 30 \text { yrs })\end{array}$} \\
\hline
\end{tabular}

The food pattern analysis, revealed that vegetable diet was not a protective factor. But "Bad fatty diet " (consumed fatty meat, fatty food or coconut milk daily) 
was significantly found as a risk factor for breast cancer $(R R=2.63,95 \% \mathrm{CI}=1.45-4.79)$, as can be seen in Table 8 .

Table 8. Relative risk on diet fatty among groups

\begin{tabular}{lcccccc}
\hline Fatty Diet & \multicolumn{2}{c}{ Case } & \multicolumn{2}{c}{ Control } & $\mathrm{Rr}$ & $95 \% \mathrm{Ci}$ \\
& $\mathrm{n}$ & $\%$ & $\mathrm{n}$ & $\%$ & & \\
\hline Good & 111 & 37.0 & 257 & 42.8 & 1.0 & \\
Average & 164 & 54.0 & 321 & 53.5 & 1.18 & $0.88-1.58$ \\
Bad & 25 & $\mathbf{8 . 3}$ & $\mathbf{2 2}$ & $\mathbf{3 . 7}$ & $\mathbf{2 . 6 3}$ & $\mathbf{1 . 4 5 - 4 . 7 9}$ \\
\hline Total & 300 & & 600 & & & \\
\hline
\end{tabular}

note: good : consumed fatty meat, fatty food or coconut milk less than once a week.

average: consumed fatty meat, fatty food or coconut milk less than three times a week.

bad : consumed fatty meat, fatty food or coconut milk milk almost daily.

Experience of 1-2 pregnancy, was identified as a risk factor $(\mathrm{RR}=1.51,95 \% \mathrm{CI}=1.02-2.23)$. Menopause and induced menopause were found to be a risk factor (RR $1.38,95 \% \mathrm{CI}=1.04-1.84$ and $\mathrm{RR}=5.96,95 \% \mathrm{CI}$ $=2.78-12.79)$. Breastfeeding or lactation for a very short term (less than 4 months) was found to be a risk factor $(\mathrm{RR}=5.44,95 \% \mathrm{CI}=1.88-15.75)$. See Tables 9,10 and 11 .

Table 9. Relative risk of pregnancy among groups

\begin{tabular}{lrrrrrr}
\hline Pregnancy & \multicolumn{2}{c}{ Case } & \multicolumn{2}{c}{ Control } & \multirow{2}{*}{$\operatorname{Rr}$} & \multicolumn{2}{l}{$95 \% \mathrm{Ci}$} \\
& $\mathrm{n}$ & $\%$ & \multicolumn{1}{c}{$\mathrm{n}$} & $\%$ & & \\
\hline None & 40 & 13.3 & 81 & 13.5 & 1.02 & $0.66-1.59$ \\
$\mathbf{1 - 2}$ & $\mathbf{6 7}$ & $\mathbf{2 2 . 3}$ & $\mathbf{9 2}$ & $\mathbf{1 5 . 3}$ & $\mathbf{1 . 5 1}$ & $\mathbf{1 . 0 2}-\mathbf{2 . 2 3}$ \\
$3-4$ & $\mathbf{7 9}$ & 26.3 & 197 & 32.8 & 0.83 & $0.59-1.18$ \\
$>5$ & 109 & 36.3 & 226 & 37.7 & 1.0 & \\
\hline Total & 295 & \multicolumn{5}{c}{596} \\
\hline
\end{tabular}

Table 10: Relative risk of menopausal status among groups

\begin{tabular}{|c|c|c|c|c|c|c|}
\hline \multirow[t]{2}{*}{ Menopause } & \multicolumn{2}{|c|}{ Cases } & \multicolumn{2}{|c|}{ Contral } & \multirow[t]{2}{*}{$\mathrm{Rr}$} & \multirow[t]{2}{*}{$95 \% \mathrm{ci}$} \\
\hline & n & $\%$ & $\Pi$ & $\%$ & & \\
\hline Not yet & 135 & 45.0 & 329 & 54.8 & 1.0 & \\
\hline Naturally & 145 & 48.3 & 263 & 43.8 & 1.38 & $1.04-1.84$ \\
\hline Induced & 19 & 6.3 & 8 & 1.3 & 5.96 & $2.78-12.79$ \\
\hline Total & 299 & & 600 & & & \\
\hline
\end{tabular}

Table 11. Relative risk of lactation among groups

\begin{tabular}{|c|c|c|c|c|c|c|}
\hline \multirow[t]{2}{*}{ Lactation } & \multicolumn{2}{|c|}{ Case } & \multicolumn{2}{|c|}{ Control } & \multirow[t]{2}{*}{$\mathbf{R r}$} & \multirow[t]{2}{*}{$95 \% \mathrm{Ci}$} \\
\hline & n & $\%$ & $n$ & $\%$ & & \\
\hline Never & 49 & 16.3 & 94 & 15.7 & 1.14 & $0.78-1.67$ \\
\hline Very short & 0 & 3.0 & 3 & 0.5 & 5.44 & $1.88-15.75$ \\
\hline Short & 7 & 2.3 & 10 & 1.7 & 5.53 & $0.58-4.04$ \\
\hline Average & 15 & 5.0 & 18 & 6.0 & 1.82 & $0.91-3.65$ \\
\hline Long & 216 & 72.0 & 472 & 78.6 & 1.0 & \\
\hline Total & 296 & & 587 & & & \\
\hline $\begin{array}{c}\text { note : very short } \\
\text { short } \\
\text { average } \\
\text { long }\end{array}$ & $\begin{array}{l}: \text { les } \\
: 4 \\
: 7 \\
: \mathrm{m}\end{array}$ & $\begin{array}{l}\text { s than } \\
6 \text { mos } \\
24 \text { mo } \\
\text { re than }\end{array}$ & $\begin{array}{l}4 \text { mos } \\
24 m\end{array}$ & & & \\
\hline
\end{tabular}

Contraception use and hormonal exposure by contraception, were found not to be a risk factors. Smoking habit was not also associated with breast cancer. But close genetic traits was an important risk factor ( $R R=$ $2.85,95 \% \mathrm{CI}=1.41-5.74)$. See table 12 .

Table 12. Relative risk of genetic trait among groups

\begin{tabular}{lrrrrll}
\hline Genetic & \multicolumn{2}{c}{ Case } & \multicolumn{2}{c}{ Control } & \multirow{2}{*}{$\operatorname{Rr}$} & \multirow{2}{*}{$95 \% \mathrm{Ci}$} \\
& \multicolumn{1}{c}{$\mathrm{n}$} & \multicolumn{1}{c}{$\%$} & \multicolumn{1}{c}{$\mathrm{n}$} & $\%$ & & \\
\hline None & 247 & 82.3 & 508 & 84.7 & 1.0 & \\
Distant & 35 & 11.7 & 79 & 13.2 & 0.91 & $0.60-1.40$ \\
Close & $\mathbf{1 8}$ & $\mathbf{6 . 0}$ & $\mathbf{1 3}$ & $\mathbf{2 . 1}$ & $\mathbf{2 . 8 5}$ & $\mathbf{1 . 4 1 - 5 . 7 4}$ \\
\hline Total & 300 & & 600 & & & \\
\hline
\end{tabular}

note :

distant : has malignancy case among family member such as father, brother, and other male family branches.

close : has malignancy case among family member such as grand-mother, mother, sister and other female family branches.

Table 13 shows that exposure to X-ray was identified as a significant protective factor $(\mathrm{RR}=0.08,95 \% \mathrm{Cl}=$ 0.020 .4 ) 
Table 13. Relative risk of $\mathrm{x}$-ray exposure among groups

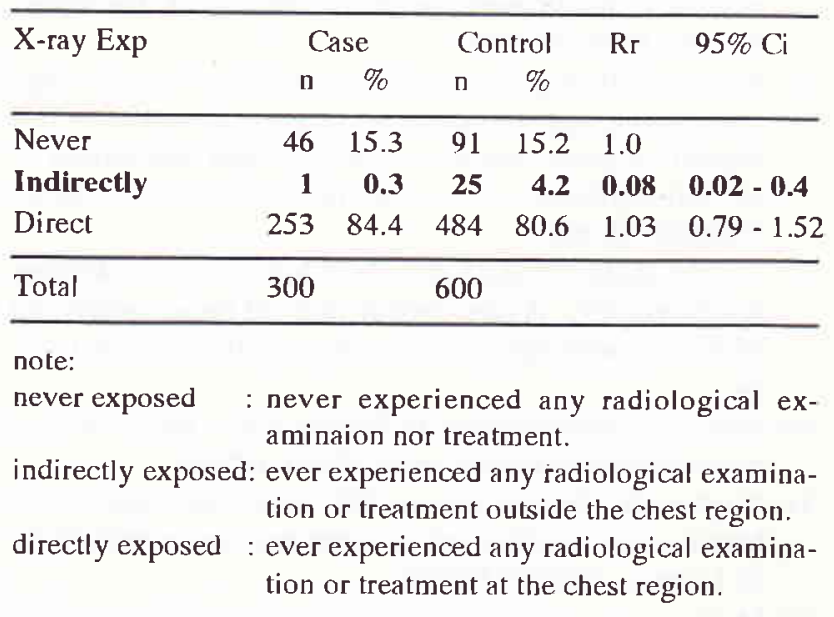

\section{DISCUSSION}

From the number of respondent, this study was one of the largest study on breast-cancer in Indonesia. One limitation of the study was that the controls were recruited only from the surgery department due to administration problem in the hospital.

The age of breast cancer cases in Indonesia was relatively younger than in Western countries and Japan. ${ }^{4,5}$ Whether such finding was due to the fact that most of the respondents were from low socio-economic strata needs clarifying.

Breast trauma was significantly shown to increase the breast cancer risk. It is of interest, since trauma has never been reported as one of risk factors, so far. Unfortunately, the type and nature of the breast trauma was unable to be described in more details.

Early menarche and late menopause have been reported to be significant risk factors for breast cancer by others. ${ }^{4,8}$ Our data did not confirm their findings. But, naturally menopause and induced menopause significantly increased the breast cancer risk.

Late first pregnancy has been also associated with increase of risk of breast cancer. ${ }^{4,5}$ Such finding was not obtained in our study. On the other hand, this study showed that experience of low number (one to two) of pregnancy provided a slight increased risk of breast cancer. This was in agreement with other reports.

Whether hormonal contraception exposure was related to increased risk of breast cancer remains intriguing. Our data did not show such relationship, which is similar to other related studies. . $^{9-11}$
Several studies has revealed the association between the preventive effect of prolonged breastfeeding or lactation with breast cancer. ${ }^{12-15}$ Our study provided such an evidence, where a woman who performed breastfeeding less than 4 months (very short duration of lactation) has 5 times higher risk to develop breast cancer.

History of breast cancer in the family, especially on the mother side has been reported as a strong risk factor. $^{4,16}$ In our study, close genetic relationship from mother side was significantly shown as a risk factor.

Body weight has a special relationship with breast cancer. Some studies indicated that obesity was related to increase the risk of breast cancer. $4,8,16-18$ Our study also found that over weight was associated with a slight increased risk of breast cancer, while obese was not. Under nutrition was also found to be a risk factor.

The present study was also aimed to analyze whether diet has a special influence on the risk for breast cancer. Similar to other reported studies we found that "bad diet" which relate to the intake of the fat in the diet increased significantly the risk of breast cancer. ${ }^{4,5}$ This finding has been very interesting, since the earlier studies did not obtain significant results. ${ }^{16,19,20}$ Actually, the general consumption of meat, milk and canned food by the Indonesian people have been considerably low. But, some ethnic groups incorporated coconut milk in their daily food, both for cooking the main dishes and desserts or snacks. Thus the data showed that fatty meat, coconut milk, whole milk and canned food were the kinds of food items related to the bad fatty diet.

Smoking and drinking in our study, were not significant risk factor. In the old generation, this two habits were not popular.

The $\mathrm{x}$-ray exposure data could not be interpreted and might be insufficient.

Beside the increasing effect of breast cancer risk of the above mentioned factors, separated and widowed marital status has a reducing effect. Not many studies explaining this phenomena, but stress related to marital situation might be conceivable to such an effect.

As a conclusion of this study, we found that the most prominent risk factors were induced menopause and short term breastfeeding or lactation i.e. less than 4 months ( RR: $5.96 \& 5.44$ respectively). The risk of getting breast cancer was two to three times increased in patients with under-weight, close genetic traits and fatty diet ( $R R: 2.2 ; 2.85$ and 2.63 respectively). The 
relationship of hormonal contraceptive with the risk of breast cancer was not shown in this study. Since fatty food was found as one of the important risk factors, further study has been extended with further nutritional analysis.

\section{Acknowledgments}

The authors are grateful to the nurses, Ms. Ros and Emi, and public health nurses, Ms. July and Ms. Erlaini for excellent epidemiological data collection. We are also indebted to EDP staffs for helping in data processing.

This work was supported by the Ministry of Education and Culture, Japan, Grants No. 01042007 and 04042013; and was partly supported by the Indonesian Cancer Foundation. This collaborative study was a part of Special Cancer Research Project in Monbusho International Scientific Research Program, with the approval of the Dean, faculty of Medicine, University of Indonesia, No. 4383 / PT02.H4.FK / E / 88.

\section{REFERENCES}

1. Ministry of Health Republic of Indonesia. Health Profile in Indonesia, (In Indonesian) 1993.

2. Prihartono J, Mangunkusumo R, Partoatmodjo P. Establishing pathology based cancer registry: Indonesian experience. In: Sasaki R, Aoki K, editors. Epidemiology and Prevention of Cancer. Proceedings of Monbusho (Ministry of Education, Science \& Culture) International Symposium on Coparative Study of Etiology \& Prevention of Cancer, Nagoya, 1989. Nagoya: The University of Nagoya Press, 1990: 211-16.

3. Cornain S, Mangunkusumo R, Nasar IM, Prihartono J. Ten Most Frequenrt Cancers in Indonesia: Pathology based Cancer Registry Data of 1988-1989. In: Cancer Registry in Indonesia. National Cancer Registry Center, Jakarta Coordinating Board, 1990.

4. Donn AS, Muir CS. Breast cancer: Epidemiology and risk factors. In: Khogali M, Omar YT, Gjorgov A, Ismail AS, editors. Cancer prevention in developing countries. Oxford: Pergamon Press, 1986: 155-66

5. Boyd NF. Epidemiology of cancer. In: Tannock IF, Hill RP, editors The Basic Science of Oncology. $2^{\text {nd }}$ ed. New York: McGraw-Hill lnc., 1992: 7-22.

6. Tjindarbumi $D$. Management and results of operable breast cancer in several hospitals in Jakarta: A 10-year survival rate observation. Indon J Oncol 1991; 2: 147-60.
7. Ingelfinger JA, Mosteller F, Thibodeau LA, Ware JH. Biostatistics in clinical medicine. 3rd ed. New York: MacGrawHill Inc., 1994: 307-330.

8. Hsieh CC, Trichopoulos D, Katsouyanni K, Yuasa S. Age at menarche, age at menopause, height and obesity as risk factors for breast cancer: associations and interactions in an international case-control study. In J Cancer 1990;46:796-800.

9. Lee NC, Rosero-Bixby L, Oberle MW, Grimaldo C, Whatley AS, Rovira EZ. A case-control study of breast cancer and hormonal contraception in Costa Rica. JNCI 1987;79:124754.

10. Stadel BV, Schlesselman JJ, Murray PA. Oral contraceptives and breast cancer. Lancet 1989;1:1257-8.

11. Stanford JL, Brinton Hoover RN. Oral contraceptive and breast cancer: results from an expanded case-control study. Br J Cancer 1989;60:375-81.

12. McTiernan A, Thomas DB. Evidence for a protective effect of lactation on risk of breast cancer in young women. Results of a case-control study. Am J Epidemiol 1986;124:353-8.

13. Siskind V, Schofield F, Rice D, Bain C. Breast cancer and breast-feeding: results from an Australian case-control study. Am J Epidemiol 1989;130:229-36.

14. Yoo-KY, Tajima K, Kuroishi T, Hirose K, Yoshida M, Miura S, Murai H. Independent protective effect of lactation against breast cancer: a case-control study in Japan. Am J Epidemiol 1992; 135: 726-33.

15. Byers T, Graham S, Rzepka T, Marshall J. Lactation and breast cancer. Evidence for a negative association in premenopausal women. Am J Epidemiol 1985; 121:664-74.

16. Kato I, Miura S, Kasumi F, Iwase T, Tashiro H, Fujita Y, et al. A case control study of breast cancer among Japanese women: with special reference to family history and reproductive and dietary factors. Breast Cancer Res Treat 1992; 24: 51-9.

17. Senie RT, Rosen PP, Rhodes P, Lesser ML, Kinne Dw. Obesity at diagnosis of breast carcinoma influents duration of disease-free survival. Ann Intern Med 1992;116:2632.

18. Wakai K, Ohno Y, Watanabe S, Sakamoto G, Kasumi F, Suzuki S, Kubo-Fujisawa N. Risk factors of breast cancer among Japanese women in Tokyo: A case-control study. J Epidemiol 1994; 4: 65-71.

19. Ohno Y. Methodology and evaluation of dietary factors in Japan. In: Mettline CI, Aoki K, editors. Recent Progress on Nutrition and Cancer. New York: Willey Liss Inc., 1990: 11-20.

20. Lee HP, Gourley L, Duffy SW, Esteve J, Lee J, Day NE. Dietary effects on breast-cancer risk in Singapore. Lancet 1991; 337: 1197-200. 